\title{
PROBLÉMY INFODÉMIE V KONTEXTE PANDÉMIE COVID-19
}

Mgr. Jakub Zábojník; jakub.zabojnik@outlook.sk; zabojnik7@uniba.sk; (Katedra knižničnej a informačnej vedy, Filozofická fakulta, Univerzita Komenského v Bratislave)

Článok je tematicky zameraný na problematiku „infodémie“, ktorá predstavuje masívne šírenie pravdivých aj nepravdivých informácií. V súčasnosti sa vo významnej miere spája s novým koronavírusom, ktorý spôsobil svetovú pandémiu. Táto "epidémia informácii" stáazuje lud'om orientáciu v hodnoverných zdrojoch aj rozhodovanie, ktoré z nich vychádza. Ako vírus, tak aj nepravdivé a neoverené informácie, ktoré sa $k$ nemu viažu, môžu byt' rovnakou hrozbou pre zdravie, život a fungovanie človeka v spoločnosti. $v$ tomto príspevku sú $v$ stručnosti opisané niektoré aspekty problematiky infodémie: predmet, t. j. rôzne typy a formy nepravdivých a neoverených informácií a jej dopady na l'udí. Zároveň sú uvádzané konkrétne príklady a prípady, ktoré ilustrujú rozsiahlost' tejto problematiky. Ciel'om článku je vymedzit' pojem infodémia, približit jej základné charakteristiky a problémy v kontexte pandémie COVID-19.

https://doi.org/10.52036/1335793X.2021.1-2.51-55

Bojujeme nielen s epidémiou, ale aj infodémiou - zaznelo z úst generálneho riaditel'a Svetovej zdravotníckej organizácie (WHO) Tedrosa Adhanoma Ghebreyesusa na Mníchovskej bezpečnostnej konferencii, ktorá sa konala vo februári 2020. Dodal, že rovnako nebezpečné ako nový vírus sú aj falošné správy, ktoré sa šíria ešte l'ahšie a rýchlejšie (Ghebreyesus 2020). L'udstvo už vyše roka čelí pandémii, kedy sa mnohé aktivity týkajúce sa rôznych oblastí života presunuli do digitáIneho prostredia. Online priestor sa stal živnou pôdou pre šírenie neoverených a nepravdivých informácií, ktoré môžu mat' $v$ období pandémie mimoriadne vážne dopady na zdravie.

Rozmach informačných a komunikačných technológií (elektronických zariadení), ako aj popularita (sociálnych) médií sú jedny z faktorov, ktoré umožňujú rýchle až exponenciálne šírenie informácií po celom svete. To môže niekedy prerást' až do takých rozmerov, že začneme hovorit' o tzv. infodémii, ktorú možno definovat' ako „nadbytok informácií - správnych aj nesprávnych - ktorý stažuje l'ud'om nájdenie dôveryhodných zdrojov a spol'ahlivých odporúčaní v situáciách, ked' ich potrebujú" (Understanding (C2020, s. 2). V tomto príspevku poukazujeme na aktuálnost' tejto témy. $\checkmark$ kontexte súčasnej pandémie vymedzujeme pojem infodémia a približujeme jej základné charakteristiky. Analyzujeme aj problémy a vážne prejavy, ktoré s ňou súvisia a doplńame ich o konkrétne príklady, ktoré dokazujú závažnost' tejto problematiky.

\section{PREDMET INFODÉMIE}

Ako je uvedené v definícii vyššie, predmetom infodé- mie sú informácie, ktoré môžu mat' rôznu mieru pravdivosti. Z tých nesprávnych môžeme spomenút tzv. dezinformácie a misinformácie. Terminológia tejto oblasti nie je konzistentná. V zahraničí sa používajú rôzne významy pre tie isté pojmy a navzájom sa aj zamieňajú. $V$ našich zemepisných šírkach sa zaužíval najmä termín dezinformácia, ktorú možno definovat' ako „informáciu, ktorá je nepravdivá a zámerne vytvorená s ciel'om poškodit' osobu, sociálnu skupinu, organizáciu alebo krajinu" (Wardle a Derakhshan (C2017, s. 20). Aspekt úmyselnosti sa nachádza aj v definícii Slovníka súčasného slovenského jazyka: „nepravdivá, vedome skreslená informácia, ktorej ciel'om je ovplyvnit' určitú skupinu l'udí, prípadne celú populáciu" (Kučera 2006). Na rozdiel od dezinformácie, misinformácia je „informácia, ktorá je nepravdivá, ale nie je vytvorená s úmyslom poškodit" (Wardle a Derakhshan 2017, s. 20). V súvislosti s neetickým prístupom sa používa aj termín malinformácia ako „informácia, ktorá je založená na skutočnosti, použivaná na spôsobenie ujmy osobe, organizácii alebo krajine" (Wardle a Derakhshan @ 2017, s. 20). V praxi môže íst' napr. o úniky dát, ktoré boli napadnuté hackermi (Wardle 2019). Týmto typom informácie sa však nebudeme zaoberat'; pozornost' budeme sústred'ovat' na nepravdivé a neoverené informácie. $V$ súčasnosti sa v literatúre a médiách často objavuje aj termín fake news. Wardleová však tvrdí, že používanie tohto pojmu nie je užitočné, pretože táto problematika sa netýka iba správ, ale celého informačného ekosystému. Podl'a nej by sme sa mali obávat nielen nechceného zdiel'ania nepravdivých informácií l'ud'mi (aj novi- 
nármi), ale aj systematických dezinformačných kampaní (Wardle 2017).

Existuje niekol'ko motivačných faktorov, ktoré sa viažu k šíreniu vyššie uvedených typov informácií: 1) finančné - napr. vytvorenie zisku prostredníctvom reklamy, 2) politické - napr. diskreditácia volebných kandidátov, ovplyvnenie verejnej mienky, 3) sociálne - spojenie/začlenenie sa do nejakej skupiny aj 4) psychologické - napr. získanie prestíže alebo posily (Wardle a Derakhshan (C2017). Karlova a Fisherová však podotýkajú, že presné dôvody, prečo l'udia šíria, ale aj veria dezinformáciám, misinformáciám či informáciám, sú tažko poznatel'né. Niektorí jednotlivci ich šíria aj napriek tomu, aby im verili. L'udská intencionalita je neurčitá a nestála a navyše niektorí jednotlivci nemusia byt ochotní vyjadrit' svoje zámery, nemusia si vediet' na ne spomenút alebo ich adekvátne formulovat' (Karlova a Fisher 2013). S problematikou informácií a dôvery sa v zahraničí používajú rôzne pojmy ako trust, mistrust, distrust či untrust. Preklad týchto termínov do slovenčiny je náročný vzhl'adom na to, že u nás sa okrem pojmov "dôvera" a "nedôvera" nepoužívajú. $V$ oblasti informačnej vedy je však toto bipolárne chápanie nepostačujúce. "Mistrust“ býva označovaná ako „zradená“ či stratená dôvera a môže byt́ príčinou informačnej chudoby a vzniku tzv. malých svetov (napr. Chatman 1991). Pozitívnym aspektom "misdôvery" ale je, že môže byt' impulzom pre hl'adanie alternatív. Ak raz niečo sklamalo jednotlivcovu dôveru, existuje šanca, že bude hladat' iné spôsoby, ktoré uspokoja jeho informačné potreby. „Distrust" môže byt' spojená napr. s konzervatívnym myslením, sústredením sa na "lokálne“ postupy či ignoranciou ostatných (Huvila 2017). Aj tieto faktory dokazujú dôležitost' dôvery pri interakcii s informáciami.

$\checkmark$ informačnom prostredí možno identifikovat' informácie s vel'kým vplyvom a dosahom. Karlova a Fisher (2013) uvádzajú, že ide o témy ako politika, financie, technológie či zdravie a sú prítomné napr. $\checkmark$ obchodnej, vládnej aj každodennej sfére. Práve po informáciách o zdraví je v súčasnosti vel'ký dopyt, ale nie všetky sú pravdivé a overené.

Ak sa vrátime $k$ definícii infodémie $v$ úvodnej časti, v ktorej sa spomína nadbytok správnych aj nesprávnych informácií, nie je možné pochybovat' o tom, že šírenie nepravdivých/neoverených informácií je v súčasnosti badatel'né, a teda môžeme hovorit' o infodémii COVID-19. Zaznamenávame informácie, ktoré sa týkajú rôznych tém ako pôvod vírusu, jeho príčina, liečba, spôsob šírenia, činnosti a politiky orgánov verejnej moci, známi aktéri (farmaceutické spoloč- nosti, firmy pôsobiace v oblasti zdravotníctva, l'udia), pripravenost' verejnosti či vývoj a prístupnost vakcíny (Understanding (C2020; Brennen et al. 2020). Tieto informácie sú však často protichodné a nepravdivé (Mohammed et al. 2021) a vyskytujú sa v rozličných typoch a formách.

\section{TYPY, FORMY A PRÍKLADY NEPRAVDIVÝCH INFORMÁCIÍ V KONTEXTE COVID-19}

Existuje množstvo typológií, ktoré sa viažu $\mathrm{k}$ nepravdivým informáciám. Približime sedem typov misinformácií a dezinformácií, ktoré identifikovala Wardleová (2019). Uvádzame k nim aj konkrétne príklady, ktoré sú alebo by potenciálne mohli byt predmetom infodémie v kontexte COVID-19.

Satira a paródia si nekladú za ciel' niekomu ubližit,' ide o druhy umenia. Za istých okolností však majú potenciál vzbudit' neporozumenie a následné šírenie a prezentovanie takéhoto obsahu ako faktu. Bývajú aj strategicky zneužívané na šírenie fám a konšpiračných teórií, aby bolo možné $v$ prípade problémov "alibisticky" vyhlásit,, že zámerom nebolo nikomu ublížit. $V$ digitálnom prostredí môže l'ahko dôjst' k dekontextualizácii obsahu a šíreniu informácií bez toho, aby bolo zretel'né, že nie sú mienené ako skutočnost' (Wardle 2019). Vhodným príkladom by mohla byt' satira publikovaná Isabel Newhousovou na portáli The Viewer, ktorej názov je Realita COVID-19 (satira) (The Reality of COVID-19 (Satire)). Okrem iného uvádza to, že téma COVID-19 je používaná na odvrátenie pozornosti od dôležitých vecí, nosenie ochranných masiek predstavuje riziko, je nutné udržiavat s ostatnými fyzické sociálne kontakty, čo sa snažia niektorí lekári a vedci zastavit' a pod. Príspevok končí slovami: „Najdôležitejšie je zapamätat' si, že to, že spravodajstvo a vzdelaní vedci robia z COVID-19 niečo vel'ké, neznamená, že tomu musia Američania verit" (Newhouse 2020). Text ako taký zjavne satiricky opisuje postoje vyskytujúce sa v populácii. Pokial' by ale nastalo jeho šírenie bez uvedenia názvu/nadpisu (alebo by bol upravený) a rubriky, nebolo by možné identifikovat pôvodný žáner a mohlo by tak nastat' neželané nedorozumenie.

Falošné spojenie sa vyskytuje vtedy, ked' nadpisy, vizuály či titulky nepodporujú obsah, ku ktorému sa viažu. $V$ elektronickom prostredí sú v tejto súvislosti používané tzv. clickbaity, ktoré sa prostredníctvom senzačného jazyka snažia naviest' ludí, aby klikli na určité odkazy (Wardle 2019). Príkladom je clickbait „Dušan (81) porazil koronu: Nebol som na respirátore, ale táto terapia ma vyliečila," ktorý sa objavil na portáli 
volimpodgoricu.me. Používatel', ktorého upúta tento text, môže byt' zvedavý, aká terapia je účinná u staršej osoby, ktorá patrí do zranitel'nejšej skupiny, čo ho vedie ku kliknutiu na daný odkaz. Po otvorení sa však dozvie, že pacient bol hospitalizovaný a liečba, ktorá bola použitá, bol kyslík (Gluščević 2020). Clickbaity ako také nemusia byt' v niektorých prípadoch škodlivé, akurát nesaturujú očakávania používatel'ov. Ak sú však spájané s nepravdivými informáciami, môže lahko dôjst' k šíreniu takéhoto obsahu na sociálnych sietach (What is clickbait? (C)1998 - 2021).

Zavádzajúci obsah. V niektorých prípadoch sa používajú pri rámcovaní príspevku informácie, ktoré sú zavádzajúce. Tento typ obsahu môže mat' rôzne formy, napríklad orezané obrázky a fotografie, selektívny výber štatistík a citátov a taktiež sem patrí aj tzv. natívna alebo platená reklama, ktorá nesie podobu formy/obsahu daného zdroja (napr. novín) (Wardle a Derakhshan (02017). Príkladom by mohla byt' situácia, v ktorej by niekto počas Vel'kej noci 2021 deklaroval prudké zlepšenie trendu vývoja epidémie na Slovensku, ale opomenul by pritom fakt, že počas týchto sviatkov nebol vykonávaný taký počet testov, ako za bežných okolností (Epidemiologická situácia 2021).

Falošný kontext. Tento typ nepravdivých informácií súvisí s priradením iného kontextu k pôvodnému obsahu (Wardle 2019). Príkladom sú príspevky, ktoré prezentujú, že poslankyňa NR SR Jana Bittó Cigániková bola odfotená pri údajne fingovanom podaní vakcíny proti COVID-19. Vyplývali zrejme z toho, že na predmetnej fotografii nebola viditel'ná injekčná striekačka. Daný záber nielenže pochádzal z obdobia spred pandémie (šlo o očkovanie proti chrípke), ale samotná striekačka bola podl'a jej vyjadrenia zakrytá rukou zdravotnej sestry (AFP Nemecko a Barca 2021). Podvodný obsah. S problematikou nepravdivých informácií súvisia aj prípady, kedy sú nejaké informácie/tvrdenia vydávané a prezentované za niekoho iného (osobu, organizáciu a pod.) (Wardle 2019). Svetová zdravotnícka organizácia sa v marci 2020 stala terčom phishingovej kampane, $v$ rámci ktorej bola používatel'om rozposielaná e-mailová správa zameraná na najnovšie informácie o koronavíruse. Súčastou nej bola aj e-kniha "MyHealth“, ktorá mala obsahovat' informácie o výskume a pôvode vírusu, ako aj odporúčania pre ochranu zdravia. Obsah správy mal motivovat' používatel'ov, aby si súbor s e-knihou stiahli a dozvedeli sa tak užitočné informácie. Správa bola vydávaná za WHO, ktorej logo bolo navyše umiestnené hned'v hlavičke obsahu. Po spustení súboru, ktorý sa nachádzal v prílohe malo dôjst' k stiahnutiu škodli- vého softvéru do používatel'ovho zariadenia (Threat Intelligence Team 2020).

Zmanipulovaný obsah vzniká úpravou/zásahom do pôvodného zdroja, často obrázkov a videí (Wardle 2019). Na sociálnej sieti sa šírilo video, ktoré hovorilo o nebezpečnosti a toxicite ochranných respirátorov. $V$ rámci neho došlo aj $k$ úprave časti videozáznamu z Úradu vlády SR, kde lekár/vedec Vladimír Krčméry zadychčane odpovedal na otázky novinárov. Táto čast' bola mechanicky spomalená, čo navonok evokovalo, že Krčméry mal problémy $s$ dýchaním (Barca a AFP Slovensko 2021).

Vyfabrikovaný obsah. Tento typ informácií je kompletne vymyslený (Wardle 2019). Príkladom boli výroky, že vakcína firmy AstraZeneca a Univerzity v Oxforde premení l'udí na opice. Vyplývali zrejme z faktu, že táto očkovacia látka obsahuje okrem iného aj šimpanzí adenovírus (Borrell 2020).

Približili sme sedem typov misinformácií a dezinformácií identifikovaných Wardleovou (2019). $V$ informačnom prostredí môžu byt' zakomponované napr. v propagande, hoaxoch, konšpiračných teóriách či pseudovede (Steinberg 2017).

\section{DOPAD INFODÉMIE NA L'UDÍ}

Nielen vírus a $s$ ním súvisiaca pandémia, ale aj nepravdivé/neoverené informácie a infodémia môžu mat' vážne následky s dopadom na zdravotný stav jednotlivca aj jeho fungovanie $v$ spoločnosti.

$\mathrm{Na}$ individuálnej úrovni môže dochádzat' $\mathrm{k}$ informačnému pret́aženiu. Ĺudia čelia množstvu informácií týkajúcich sa vírusu, ktoré pochádzajú z rôznych zdrojov a médií. Informácie sú však často protichodné a nepravdivé, čo môže l'ud'om stážovat' rozlíšenie faktu of fikcie a podniknutie vhodných krokov (Mohammed et al. 2021). To môže byt' náročné v prípade, ak je potrebné učinit' rýchle rozhodnutie, ale nie je dostatok času na preštudovanie všetkých dôkazov. Ĺudia môžu v infodémii pocitovat' aj úzkost', depresie, ohromenie či emočné vyčerpanie (Understanding (C2020).

Škodlivé informácie môžu priamo ohrozit' nielen zdravie, ale aj život človeka. Objavili sa rôzne fámy ako "Pitie bielidla môže zničit' vírus", "Pitie alkoholu môže zničit vírus" "Pitie kravského moču a kravský trus môžu liečit' koronavírus" (Islam et al. 2020). Jednou zo zasiahnutých krajín nepravdivými informáciami bol Irán. Tamojšiu epidemickú situáciu skomplikovali falošné tvrdenia o účinnosti konzumácie dezinfekčných prostriedkov a alkoholu za účelom prevencie a liečby COVID-19. Podl'a dát z miestnych inštitúcii bolo v období od 23. februára do 2. mája v súvislosti s otra- 
vou metanolom hospitalizovaných 5876 pacientov, pričom 534 až 800 (údaje z databáz sa líšia) zomrelo. $\checkmark$ niektorých prípadoch (dospelých aj detí), ktoré neskončili fatálne, došlo $\mathrm{k}$ poškodeniu zraku či slepote. Autori však podotýkajú, že z dát nie je jasné, u kol'kých l'udí sa dané prípady stali na základe nasledovania nepravdivých informácií alebo z rekreačnej konzumácie (Hassanian-Moghaddam et al. 2020).

Na spoločenskej úrovni môže dochádzat' k tzv. sociálnej stigmatizácii, teda vylúčeniu jedinca zo spoločnosti na základe určitého rysu (Goffman 2003). $\checkmark$ tomto prípade ide o kontakt s koronavírusom, či už priamo jeho infekciou alebo prácou $v$ prostredí, kde sa vyskytuje (napr. nemocnica). Číñania aj ostatní l'udia s ázijským pôvodom čelili verbálnym aj fyzickým útokom. Objavili sa tvrdenia ako "Číñania sú bioteroristi", "Číñania sú necivilizovani" či "Každá choroba prišla z Číny". Situácii neprospeli ani výroky ako "č́nsky vírus" alebo "wu-chanský vírus" (Islam et al. 2020). Nielen l'udia ázijského pôvodu, ale aj zdravotnícky personál už čelil stigmatizácii. Niekol'ko indických lekárov, ktorí liečili infikovaných pacientov, bolo násilne vystáahovaných zo svojich domovov z dôvodu obáv o možné šírenie choroby. Dôvodom vytvárania stigmy bola nedostatočná informovanost' l'udí o víruse (Kalra a Ghoshal 2020).

Boli zdokumentované aj prípady, kedy organizácie, resp. usporiadatelia podujatí nasledovali nepravdivé, resp. neoverené informácie. Napríklad v juhokórejskom kostole bola prostredníctvom flaše s rozprašovačom návštevníkom do úst vstrekovaná slaná voda domnievajúc sa, že táto je účinná proti šíreniu vírusu. Toto „opatrenie“ však malo za následok 46 infikovaných, pretože flaša nebola priebežne pred každým použitím dezinfikovaná (Chan-kyong 2020). V Indii sa zas uskutočnil večierok, ktorého sa zúčastnilo 200 l'udí a jeho účelom bolo pitie kravského moču veriac, že chráni pred vírusom, a to aj napriek tomu, že to nebolo vedecky dokázané (Siddiqui 2020).

\section{ZÁVER}

Infodémia súvisiaca s COVID-19 má širokospektrálny dosah. Ako dezinformácie, tak aj misinformácie (hoci sú šírené neúmyselne) môžu mat́ nepriaznivý vplyv na psychické a fyzické zdravie a reputáciu jednotlivcov, skupín aj organizácií. Množstvo informácií stažuje l'ud'om nájdenie dôveryhodných zdrojov, rozlíšenie pravdy od fikcie, ako aj realizáciu vhodných krokov a postupov. Dopyt po užitočných informáciách a obavy l'udí z koronavírusu môžu byt' zneužité aj pre rôzne kybernetické zločiny (Threat Intelligence Team 2020). Infodémia je rozšírená v mnohých krajinách sveta vrátane Slovenska. Portály, agentúry aj orgány špecializujúce/zaoberajúce sa nepravdivými a neoverenými informáciami pravidelne informujú verejnost o konkrétnych prípadoch. Môžu sa vyskytovat' v rôznych formách, napr. hoaxoch, fámach, konšpiračných teóriách atd'.

Infodémia, ktorá komplikuje pandémiu, predstavuje výzvu pre jej riadenie. Dosiahnutie „imunity“ l'udí voči nepravdivým/neovereným informáciám možno uskutočnit' prostredníctvom vzdelávania a zdokonal'ovania informačnej gramotnosti, ale aj množstvom d'alších stratégií, ktoré však predstavujú iný rozmer tejto problematiky. $\mathrm{V}$ tomto príspevku sme sa sústredili na základné charakteristiky infodémie, jej predmet (dezinformácie, misinformácie atd'.) a dopady na l'udí.

\section{Zoznam použitej literatúry}

AFP NEMECKO a R. BARCA, 2021. Zavádzajúce video: Respirátory sú bezpečné, podliehajú európskym normám. Čast́ záznamu s Krčmérym bola zmanipulovaná. AFP Fakty [online]. AFP [cit. 2021-05-13]. Dostupné na: https://fakty.afp.com/zavadzajuce-video-respiratory-su-bezpecne-podliehaju-europskym-normam-cast-zaznamu-s-krcmerym-bola

BARCA, R. a AFP Slovensko, 2021. Fotografia, ktorá mala vraj dokazovat', že Cigánikovú očkovali len naoko, je 2 a pol roka stará; poslankyňa bola proti Covidu zaočkovaná AstraZenecou. AFP Fakty [online]. AFP [cit. 2021-05-13]. Dostupné na: https://fakty.afp. com/fotografia-ktora-mala-vraj-dokazovat-ze-ciganikovu-ockovali-len-naoko-je-2-pol-roka-stara-poslankyna

BORRELL, J., 2020. The essential fight against disinformation and manipulation. EEAS [online]. European Union External Action Service [cit. 2021-05-13]. Dostupné na: https://eeas.europa.eu/ headquarters/headquarters-homepage/91038/essential-fight-against-disinformation-and-manipulation en

BRENNEN, J. S. et al., 2020. Types, sources, and claims of COVID-19 misinformation. In: Reuters Institute [online]. [cit. 202105-15]. Dostupné na: https://reutersinstitute.politics.ox.ac.uk/ types-sources-and-claims-covid-19-misinformation

Epidemiologická situácia, 2021 [online]. Bratislava: Ministerstvo zdravotníctva Slovenskej republiky [cit. 2021-05-14]. Dostupné na: https://korona.gov.sk/wp-content/uploads/2021/04/epidemiologicka situacia 210406.pdf

GHEBREYESUS, T. A., 2020. Munich Security Conference. In: WorId Health Organization [online]. World Health Organization [cit. 2021-05-14]. Dostupné na: https://www.who.int/director-general/speeches/detail/munich-security-conference

GLUŠČEVIĆ, N., 2020. Hunt for clickbait. UNICEF Montenegro [online]. [cit. 2021-05-13]. Dostupné na: https://www.unicef.org/ montenegro/en/stories/hunt-clickbait

GOFFMAN, E. Stigma: Poznámky o způsobech zvládaní narušené identity. Praha: Slon, 2003. ISBN 80-86429-21-0. 
HASSANIAN-MOGHADDAM, $\mathrm{H}$. et al., 2020. Double trouble: methanol outbreak in the wake of the COVID-19 pandemic in Iran-a cross-sectional assessment. In: Critical Care [online]. Berlín: Springer Nature, roč. 24, č. 1 [cit. 2021-5-14]. ISSN 13648535. Dostupné na: https://www.ncbi.nlm.nih.gov/pmc/articles/ PMC7344025/

HUVILA, I., 2017. Distrust, mistrust, untrust and information practices. In: Information Research [online]. Borås: University of Borås, roč. 18, č. 1 [cit. 2021-05-14]. ISSN 1368-1613. Dostupné na: http://informationr.net/ir/22-1/isic/isic1617.html

CHANG-KYONG, P., 2020. Coronavirus: saltwater spray infects 46 church-goers in South Korea. This Week in Asia [online]. [cit. 2021-05-13]. Dostupné na: https://www.scmp.com/week-asia/ health-environment/article/3075421/coronavirus-salt-water-spray-infects-46-church-goers

CHATMAN, E. A., 1991. Life in a small world: Applicability of gratification theory to information-seeking behavior. In: Journal of the American Society for Information Science [online]. Hoboken: John Wiley \& Sons, roč. 42, č. 6, s. 438-449 [cit. 2021-05-14]. ISSN 0002-8231. Dostupné na: https://asistdl.onlinelibrary.wiley. com/doi/10.1002/(SICI)1097-4571(199107)42:6\%3C438::AID-ASI6\%3E3.0.CO;2-B

ISLAM, M. S. et al., 2020. COVID-19 - Related Infodemic and Its Impact on Public Health: A Global Social Media Analysis. In: The American Journal of Tropical medicine and hygiene [online]. Roč. 103, č. 4 [cit. 2021-05-15]. Dostupné na: https://www.ajtmh.org/ content/journals/10.4269/ajtmh.20-0812?crawler=true

KALRA, A. a D. GHOSHAL, 2020. Indian doctors evicted over coronavirus transmission fears: medical body. Reuters [online]. [cit. 2021-05-13]. Dostupné na: https://www.reuters.com/article/us-health-coronavirus-india-doctors-idUSKBN21C12G

KARLOVA, N. a K. E. FISHER, 2013. A social diffusion model of misinformation and disinformation for understanding human information behaviour. In: Information research [online]. Roč. 18, č. 1 [cit. 2021-05-15]. Dostupné na: http://informationr.net/ir/18-1/ paper573.htm|\#.YJ01e5MzZ-U

KUČERA, M., 2006. Dezinformácia. In: BALÁŽOVÁ, L'. et al. Slovník súčasného slovenského jazyka [online]. Bratislava: Veda. ISBN 80224-0932-4. Dostupné na: https://slovnik.juls.savba.sk/?w=dezinform\%C3\%A1cia\&s=exact \&c=001e \&cs=\&d=sssj\&d=hssj\&d=bernolak \&d=noundb\&d=orient $\& d=$ locutio $\& d=o b c e \& d=$ priezvis$k a \& d=u n \& d=p s k c s \& d=p s k e n \#$

MOHAMMED, M. et al., 2021. Assessment of COVID-19 Information Overload Among the General Public. In: Journal of Racial and Ethnic Health Disparities [online]. Berlín: Springer Nature [cit. 2021-5-13]. ISSN 2197-3792. Dostupné na: https://pubmed.ncbi. nIm.nih.gov/33469869/

NEWHOUSE, I., 2020. The Reality Of COVID-19 (Satire). The Viewer [online]. Arden Hills: Mounds View High School [cit. 2021-05-13]. Dostupné na: https://www.mvviewer.org/editorials/2020/10/01/ the-reality-of-covid-19/

SIDDIQUI, D, 2020. Hindu group offers cow urine in a bid to ward off coronavirus. Reuters [online]. [cit. 2021-05-13]. Dostupné na: https://www.reuters.com/article/us-health-coronavirus-indiacow-urine-pa-idUSKBN2110D5

STEINBERG, L., 2017. Infographic: Beyond Fake News - 10 Types of Misleading News - Seventeen Languages. EAVI [online]. European Association for Viewers Interests [cit. 2021-05-13]. Dostupné na: https://eavi.eu/beyond-fake-news-10-types-misleading-info/ THREAT INTELLIGENCE TEAM, 2020. Cybercriminals impersonate World Health Organization to distribute fake coronavirus e-book. Malwarebytes Labs [online]. Cork: Malwarebytes [cit. 2021-0513]. Dostupné na: https://blog.malwarebytes.com/social-engineering/2020/03/cybercriminals-impersonate-world-health-organization-to-distribute-fake-coronavirus-e-book/

Understanding the Infodemic and Misinformation in the fight against COVID-19, C2020 [online]. Washington: Pan American Health Organization [cit. 2021-05-13]. Dostupné na: https://iris. paho.org/bitstream/handle/10665.2/52052/Factsheet-infodemic eng.pdf? sequence $=14$

WARDLE, C. a H. DERAKHSHAN, C2017. INFORMATION DISORDER: Toward an interdisciplinary framework for research and policy making [online] Štrasburg: Council of Europe [cit. 2021-05-13]. Dostupné na: https://rm.coe.int/information-disorder-toward-an-interdisciplinary-framework-for-researc/168076277c

WARDLE, C. a H. DERAKHSHAN, 2018. Thinking about 'information disorder': formats of misinformation, disinformation, and malinformation. In: IRETON, CH. a J. POSETTI. Journalism, fake news \& disinformation: handbook for journalism education and training [online]. Paríz: UNESCO, s. 43-54. ISBN 978-92-3-1002816. Dostupné na: https://en.unesco.org/sites/default/files/f. ifnd handbook module 2.pdf

WARDLE, C., 2017. Fake news. It's complicated. First Draft [online]. First Draft [cit. 2021-05-13]. Dostupné na: https://firstdraftnews.org/latest/fake-news-complicated/

WARDLE, C., 2019. First Draft's Essential Guide to Understanding Information Disorder [online]. First Draft [cit. 2021-0513]. Dostupné na: https://firstdraftnews.org/wp-content/ uploads/2019/10/Information Disorder Digital AW.pdf?x76701 What is clickbait?, (c1998-2021. GCFGlobal [online]. Goodwill Community Foundation [cit. 2021-05-13]. Dostupné na: https:// edu.gcfglobal.org/en/thenow/what-is-clickbait/1/ 